\title{
New First Report of Foliar Phytoplasma Disease on Bartondi Plant in India
}

\author{
Prakash P. Sarwade $^{1 *}$, Kavita P. Sarwade ${ }^{2}$ and Sachin S. Chavan ${ }^{1}$
}

${ }^{1}$ Department of Botany, Shikshan Maharshi Guruvarya R. G. Shinde Mahavidyalaya, Bavachi Road, Paranda District, Osmanabad-413 502, Maharashtra, India ${ }^{2}$ Department of Botany, Shankarrao Patil Mahavidyalaya, Pardi road Bhoom, District, Osmanabad. 413 504, Maharashtra, India

\begin{abstract}
A foliar phytoplasma disease symptoms were observed on Morinda citrifolia L. The plants affected with leaf suffer a greatly reduced growth and become stunted or dwarfed, shrinkages upwards and inwards. The leaf lamina shrinkage from the petiole to the tip. Infected shoots are typically shorter and bear smaller leaves. The present investigation was carried out on the symptomatology of this disease. It is confirmed as phytoplasma like organisms on Morinda spp. plant for first new report in India.
\end{abstract}

\section{Keywords: Morinda citrifolia L; Foliar; Phytoplasma}

\section{Short Communication}

Morinda citrifolia L. (Family: Rubiaceae) is commonly known as bartondi. Its native range extends through Southeast Asia and Australia and the species is now cultivated throughout the tropics and widely naturalized [1]. It is a large shrub to medium tree varying from three meters to twelve meter high. The white flowers occur in the leaf axils in clusters mainly in summer and autumn. Parts of the plants including fruit, leaves, root, stem and bark are used in folk medicine in Polynesian cultures to treat menstrual cramps, bowel irregularities, diabetes, liver diseases and urinary tract infections [2]. It has been shown that these are effective against minimizing the symptoms of life style-related diseases such as atherosclerosis vascular disorders [2], hypertension [3], stroke [4], diabetes, cancer [5], and contains some antioxidative, anti-inflammatory ingredients [3]. It shows antioxidant [6], antitumor [7] and angiotensin converting enzyme inhibitor activities [8]. It is an edible plant and its fruit juice is a popular drink.

In the present study investigation was carried out on the symptomatology of this disease. Observations of foliar phytoplasma disease of bartondi plants at the naturally infected fields at the different places of Paranda, Dist. Osmanabad (M.S) India between 2014 and Jan

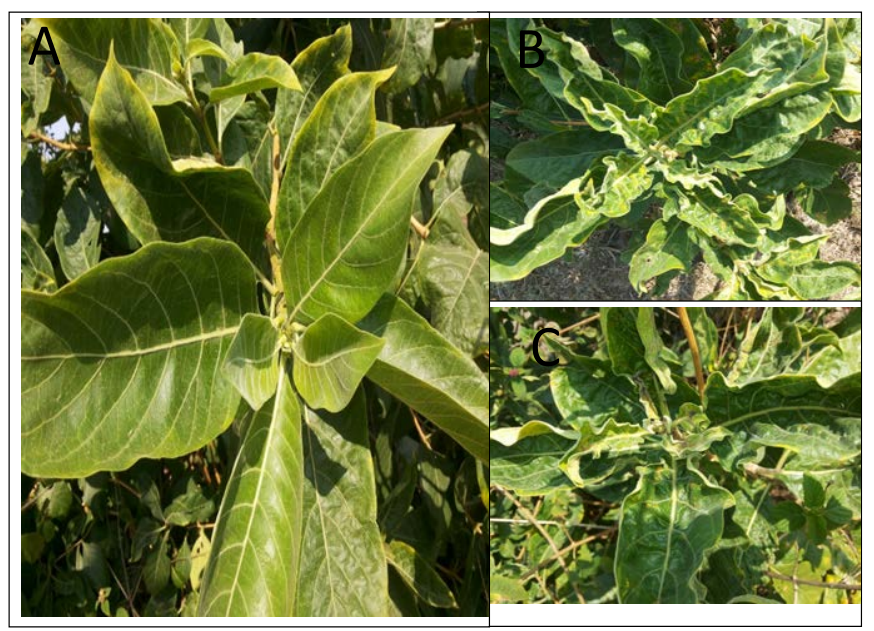

Figure 1: Foliar Phytoplasma Disease of Bartondi Plant: (A) Healthy plant in the field. (B and C) Foliar Phytoplasma affected plant in the field a shoot showing Infected shoot are typically shorter and smaller leaves.
2015. Infected shoots are typically shorter and smaller leaves. Bushy appearance due to excessive stunting of shoots, reduced intermodal length and production of reduced leaf in an apical axis (Figure 1) are the most common symptoms.

The plants affected with leaf suffer a greatly reduced growth and become stunted or dwarfed, shrinkages upwards and inwards. The leaf lamina shrinkage from the petiole to the tip. Symptoms to develop visible in rainy to winter season. According to the symptoms it is confirmed as phytoplasma like organisms. The infected plant specimen is deposited at Department of Botany, Shikshan Maharshi Guruvarya R. G. Shinde Mahavidyalaya, Bavachi Road, Paranda Dist. Osmanabad. (M.S.) India.The scanning of available literature shows that new first report of foliar phytoplasma disease on bartondi plants in Maharashtra, India.

The different diseases on Morinda plants were previously reported by Scot C. Nelson [9] such as Black flag of noni, Sooty mold, Noni rootknot disease, Stem rot, Pests known to attack noni in Hawaii include aphids (Aphis gossypii), ants, scales (the green scale), mites, whiteflies (fringe guava whitefly), and slugs.

\section{References}

1. Nelson SC (2005) Species Profiles for Pacific Island Agroforestry: Morinda citrifolia (noni). Traditional Tree Initiative.

2. Wang MY, West BJ, Jensen CJ, Nowicki D, Su C, et al. (2002) Morinda citrifolia (Noni): a literature review and recent advances in Noni research. Acta Pharmacol Sin 23: 1127-1141.

3. Harada S, Hamabe W, Kamiya K, Satake T, Yamamoto J, et al. (2009) Preventive effect of Morinda citrifolia fruit juice on neuronal damage induced by focal ischemia. Biol Pharm Bull 32: 405-409.

4. Nayak BS, Sandiford S, Maxwell A (2009) Evaluation of the Wound-healing Activity of Ethanolic Extract of Morinda citrifolia L. Leaf. Evid Based Complement Alternat Med 6: 351-356.

*Corresponding author: Prakash P. Sarwade, Department of Botany, Shikshan Maharshi Guruvarya R. G. Shinde Mahavidyalaya, Osmanabad-413 502, Maharashtra, India, Tel: +91 9850547892; E-mail: ppsarwade@gmail.com

Received January 30, 2015; Accepted March 25, 2015; Published March 30, 2015

Citation: Sarwade PP, Sarwade KP, Chavan SS (2015) New First Report of Foliar Phytoplasma Disease on Bartondi Plant in India. J Plant Pathol Microb 6: 260. doi:10.4172/2157-7471.1000260

Copyright: (c) 2015 Sarwade PP, et al. This is an open-access article distributed under the terms of the Creative Commons Attribution License, which permits unrestricted use, distribution, and reproduction in any medium, provided the original author and source are credited. 
Citation: Sarwade PP, Sarwade KP, Chavan SS (2015) New First Report of Foliar Phytoplasma Disease on Bartondi Plant in India. J Plant Pathol Microb 6: 260. doi:10.4172/2157-7471.1000260

Page 2 of 2

5. Takashima J, Ikeda Y, Komiyama K, Hayashi M, Kishida A, et al. (2007) New constituents from the leaves of Morinda citrifolia. Chem Pharm Bull (Tokyo) 55: $343-345$

6. Zin ZM, Hamid AA, Osman A (2002) Antioxidative activity of extracts from Mengkudu (Morinda citrifolia L.) root, fruit and leaf. Food Chem. 78: 227-231.

7. Furusawa E, Hirazumi A, Story S, Jensen J (2003) Antitumour potential of a polysaccharide-rich substance from the fruit juice of Morinda citrifolia (Noni) on sarcoma 180 ascites tumour in mice. Phytother Res 17: 1158-1164.
8. Shinya $Y$, Juno O, Masanobu S, Isafumi M, Yasuhiro O et al.(2002) Inhibition of angiotensin I converting enzyme by Noni [Morinda citrifolia] juice. Journal of the Japanese Society for Food Science and Technology 49: 624-627.

9. Nelson SC (2003) "Noni cultivation in Hawaii" Proceedings of the Hawaii Non Conference, S.C. Nelson (ed.), University of Hawaii at Manoa, College of Tropical Agriculture and Human Resources. Fruits and Nuts (http://www.ctahr. hawaii.edu/). 